Grant H. Lundberg and Tom Priestly

Brigham Young University and University of Alberta

\title{
Pitch Opposition in Sele: Slovene Tone Loss in Austrian Carinthia
}

Prispevek opisuje strojno razčlembo sodobnega stanja tonemskih nasprotij v slovenskem govoru vasi Sele na avstrijskem Koroškem. Študija, ki je bila izvedena poleti in jeseni 2007, kaže, da so tonemska nasprotja dosledno ohranjena pri starejši generaciji, medtem ko se pri mlajši izgubljajo, čeprav ne dosledno.

This paper is a description of an instrumental analysis of the contemporary state of tonemic oppositions in the Slovene micro-dialect of Sele in Austrian Carinthia. The study, conducted during the summer and fall of 2007, indicates that tonemic oppositions are uniformly preserved among the older generation and being lost, although not uniformly, among the younger generation.

\section{Introduction}

It is well known that peripheral territories are places of enhanced interest in dialectology because they are likely to contain archaisms, i.e., internal dialectal retentions, as well as innovations as a result of external language contact. ${ }^{1}$ The situation in the Slovene dialects in Austrian Carinthia is a good illustration of this point. Ramovš indicates that the Carinthian Slovene dialects are full of archaisms (1935: 2). Most of these dialects have indeed maintained archaic tonal oppositions, although innovative accentual peculiarities are not uncommon (Greenberg 2000: 25). In this light the prosodic systems of these dialects are doubly interesting because in other peripheral dialect regions external language contact has been identified as the likely cause of tone loss. By contrast, here it appears that the intense two-way contact between Carinthian Slovene and Bavarian dialects has helped to preserve tonemic distinctions (Neweklowsky 1999: 23, Greenberg 56; but see Reindl 60-62). Moreover, the specific nature of these distinctions in the dialects of Austrian Carinthia is not well known and, therefore, is worth a closer examination. This paper is a description of an instrumental analysis of the realization of tonemic oppositions in Sele, a micro-dialect within the larger Slovene dialect area of Rož in Austrian Carinthia. Sele is located just north of the Slovene border and about 20 kilometers south of Klagenfurt. See figure 1 below.

\section{Background}

Although there have been a number of descriptions and analyses of tone in the Slovene literary standard (See Toporišič, Srebot-Rejec and Jurgec for a summary of

\footnotetext{
${ }^{1}$ This paper was prepared for and delivered at the Sixteenth Biennial Balkan and South Slavic Conference in Banff, Alberta, Canada on 2 May 2008.
} 
previous studies), there have been far fewer studies of tone in Slovene dialects, and Slovene dialects in Austrian Carinthian are not an exception. The following is a brief discussion of what is known about tonemic oppositions in this area.

Ramovš in a general overview of the Carinthian dialects states that rising accents, or acute, and falling, or circumflex, are distinguished primarily in long syllables. ${ }^{2}$ In short syllables rising and falling are differentiated only by several relatively recent accent retractions. Finally, he states that even the opposition in long syllables diminishes in the western part of Carinthia until some dialects have no tonal oppositions at all (4). ${ }^{3} 0.08$

Figure 1: Dialect Map of Slovenia

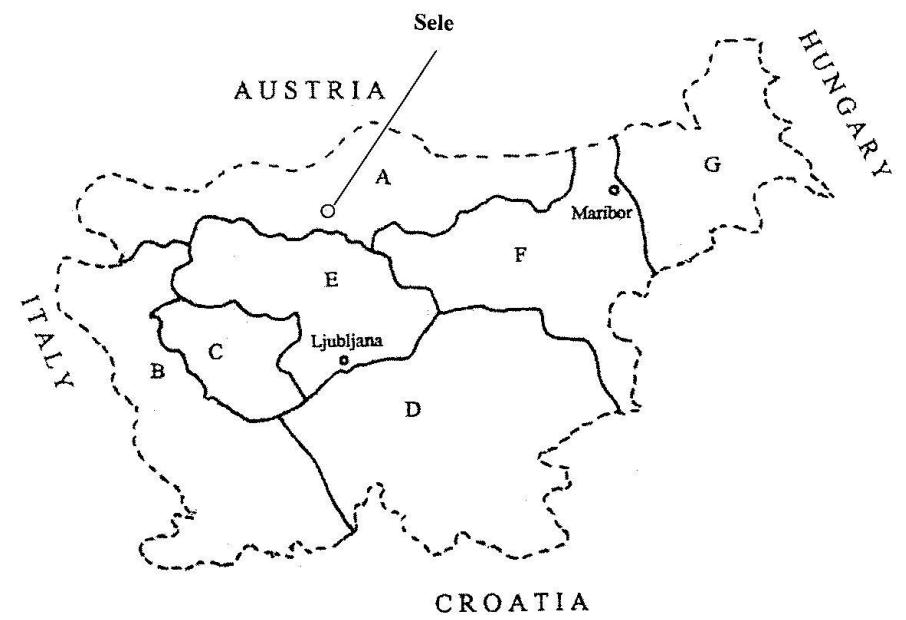
A Carinthia
D Lower Carniola
G Pannonia
B Littoral
E Upper Carniola
C Rovte
F Styria

In 1939 Isačenko published his Narečje vasi Sele na Rožu. This study does not rely on experimental or instrumental analyses; Isačenko relies on his own ability to hear tonal distinctions. He claims that rising and falling tones are distinguish-

${ }^{2}$ The rising tone in Slovene studies is traditionally called the acute or the low tone. The falling tone is known as the circumflex or high tone. In the remainder of this paper they will be called rising and falling because those terms most closely match their observed shape in the dialects of Carinthia studied here.

${ }^{3}$ Logar provides a much more detailed and accurate overview of tonal oppositions in the Carinthian dialects (226). It is only briefly mentioned here because it is based on Isačenko and Neweklowsky, a discussion of whose work follows below. 
able in both long and short syllables and in all syllable positions including final (23). Figure 2 illustrates these oppositions using forms from Isačenko's study. ${ }^{4}$

Figure 2: Narečje vasi Sele na Rožu, 1939

\begin{tabular}{|c|c|}
\hline$\underline{\text { Rising }}$ & $\underline{\text { Falling }}$ \\
\hline \multicolumn{2}{|c|}{ long } \\
\hline $\begin{array}{l}\text { rást 'to grow' } \\
\text { quás 'ear of corn' }\end{array}$ & $\begin{array}{l}\text { râst 'growth' } \\
\text { quââs 'yeast' }\end{array}$ \\
\hline \multicolumn{2}{|c|}{ short } \\
\hline $\begin{array}{l}\text { ì̀x 'yoke' } \\
\text { bọ̀b (nom. pl.) 'bean }\end{array}$ & $\begin{array}{l}\text { ỉäx 'south' } \\
\text { böb (nom. sg.) }\end{array}$ \\
\hline
\end{tabular}

In 1973 Gerhard Neweklowsky published his Slowenische Akzentstudien. This monograph is a careful and reliable instrumental study of the accentual systems in the three main Slovene dialect areas of Austrian Carinthia. Neweklowsky did not study the particular village dialect or surrounding area that concerns us here, Sele, but he did examine the larger dialect area which contains Sele, the dialect area of Rož. Neweklowsky claims that in this region there are no tonal oppositions on short syllables (236) and that tonal oppositions are realized in long syllables only in non-final position (141). He also emphasizes the point that tone in Rož is realized across the entire word rather than on only the accented syllable. Therefore, the most salient feature in differentiating the contrasting rising and falling accents is the relative height of the tonic and post-tonic syllables (141).

Neweklowsky's description of tonal oppositions in Rož is different from Isačenko's descriptions of the village of Sele within Rož. This apparent contradiction may represent the true situation: it is possible that the village dialect of Sele differs significantly from other parts of Rož. After all, Neweklowsky's study makes it very clear that there is significant accentual variation across Carinthian dialects. The differences between Isačenko's and Neweklowsky's descriptions could also be a factor of time and the generation of the informants in the two studies, for nearly thirtyfive years separate the investigations. Additional study of the modern dialect in and around Sele is expected to shed some light on the situation.

\section{Experiment}

This study seeks to answer three questions: 1) What is the status of tonemic oppositions in Sele? 2) Are there differences in the realization of tones between the older

${ }^{4}$ For a thorough critique of Isačenko's study see Priestly's 1994 article in Slavistična revija. Priestly argues that we ought to defer judgment on some of Isačenko's claims about tonal oppositions in Sele. 
and the younger generations? and 3) given the dialect differences, are there differences among the younger speakers if one parent is from a Carinthian village outside of Rož? The study is based on the speech of seven informants, three from the older generation, i.e., over 50 years old, and four from the younger generation, all under 32 years old. ${ }^{5}$ All of the informants were natives of the village. The informants from the older generation were between the ages of 92 and 54, and the informants from the younger generation were between 32 and 26. Of the four informants in the younger sample, one male and one female informant had both parents who were native to the village and one male and one female had one parent from Sele and one parent from Podjuna. Podjuna is a neighboring region of Carinthia, where the dialects also have tonemic oppositions, but those oppositions are organized differently from Rož (see further below). In both cases the father was from Sele, and the mother was from Podjuna; it is normal here, as elsewhere, for wives to migrate to the village after marriage. Also, the mothers' influence on growing children's speech is expected to be greater than the fathers'. Although the sample is admittedly very small, these subjects are considered as representative of the majority of Selane in their age-groups with respect to their overall command and use of the village dialect, and their tonemic system(s) are probably also representative.

\title{
Figure 3
}

\author{
Informants ${ }^{6}$ \\ Older Generation \\ 2 Females: 1916 (1), 1942 (2) \\ 1 Male: 1954 (3) \\ $\underline{\text { Younger Generation }}$ \\ Both Parents from Sele \\ Female: 1976 (4) \\ Male: 1985 (5) \\ Parent from Sele, Parent from Podjuna \\ Female: 1986 (6) \\ Male: 1982 (7)
}

\footnotetext{
${ }^{5}$ We originally interviewed and recorded eight informants, four from the older generation and four from the younger, but we excluded one of the older informants, 75 years old, from the study because his speech had no tonemic oppositions. This individual is acknowledged in the village as an avtodidakt with a semi-standard way of speaking, and his pronunciation of words during the interview was very slow and artificial. It seems likely, at least, that his delivery obscured the natural tone contours.

${ }^{6}$ The numbers in parentheses are simply a way to designate each informant in the paper without using names.
} 
The language of the informants' education for the informants differed greatly, reflecting the evolving status of the minority in Austrian Carinthia. \#1 and \#2 had primary schooling only: for \#1, in the 1920s, the legacy of 'utraquistic' education meant minimal bilingualism which was in fact nearly all in German; for \#2, immediately after World War Two, most of the classes were in German, but although the principal was markedly pro-German, the primary teachers encouraged the use of Slovene. \#3 also had primary schooling in German (except for Slovene language classes), but he went on to the newly opened Slovenska gimnazija in Celovec, where nominal bilingualism was de facto mostly in Slovene. \#4 had bilingual, mostly Slovene, primary and secondary schooling, and also studied Slovene at university level. \#\# 5 and 7 also had bilingual, mostly Slovene, primary and secondary schooling; \#6, after mostly Slovene primary school, studied at a secondary school where most of the classes were in German. All seven informants (like the majority of Selane) were born and raised in staunch Slovene-speaking homes.

Ideally an instrumental study to establish tonal oppositions would begin with a list of true minimal pairs in which the only difference between the two words is accent type. Establishing such a list from an unwritten dialect code is difficult because the possible vocabulary list is smaller and more cumbersome to search. It is also difficult because, firstly, the functional load of the oppositions in this dialect is small and, secondly, many of the true minimal pairs in the dialect corpus are simply different grammatical cases of the same word. Furthermore, it is difficult to create natural contexts in which an informant can recognize and use these forms in opposition. With these problems in mind, the authors collected a list of near minimal pairs on which opposing rising and fall tones were expected. Some of the word comparisons are true minimal pairs, but most are slightly different words with similar syllable structures. The syllable structure was carefully matched because the quality of the compared pre and post vocalic segments can influence fundamental frequency values (Hombert). Figure 4 contains a list of the dialect forms that were tested in the study. ${ }^{7}$

\title{
Figure 4
}

\author{
CVCV \\ Long Rising \\ rama 'shoulder' \\ paša 'pasture' \\ buča 'pumpkin' \\ duša 'soul' \\ juni 'June' \\ doma 'at home' \\ hura 'hour' \\ həəba 'mushroom'
}

${ }^{7}$ These forms all come from the second author's corpus of Sele dialect materials; in this corpus words with short vowels have rising and falling accents as described by Isačenko; these can be reconstructed, in instances where Isačenko does not list the word, from contemporary vocalic distinctions. 







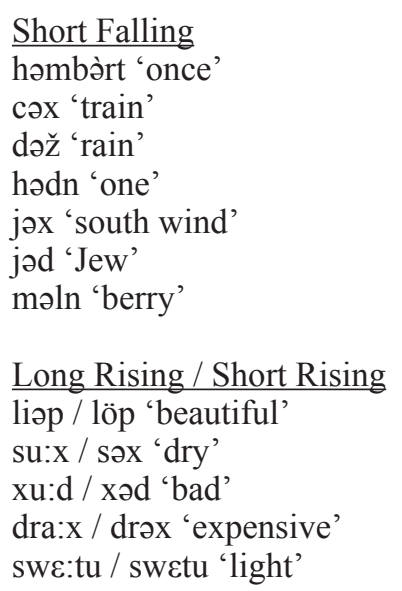

In order to elicit the desired forms in a neutral sentence position, the informants, all of whom are fluent in German, were asked in dialect, "How do you say $\underline{\mathrm{XXX}}$ in your dialect?" The prompt word was given in German. Then a carrier sentence was modeled for the informants, and they were asked to respond to the question in dialect, "We/I say YYY in our dialect." They replaced the German prompt with the local dialect form.

For example, the interviewer might ask, "qəqu rečiš die Schulter po scəlščim?" The informant's response would be, "rečim rama po seəlščim." The words were tested in this way and digitally recorded from all seven informants. The fieldwork was done during the summer of 2007. During the fall of 2007 and early spring of 2008 these recordings were analyzed using Praat 4.6.13.

\section{Results}

\subsection{Representatives of the older generation}

This analysis shows that the older generation clearly has tonemic oppositions on long non-final syllables. Often the accented syllables have contour distinctions: the original acute has a rising contour, while the original circumflex has an early peak and a falling contour through the remainder of the accented syllable. This contour is not always present on non-final syllables, but the tone is consistently realized over the entire word. Therefore, the relative height of the tonic and post tonic syllables is the clearest indication of the tonal contrast. In words with the rising tone, the fundamental frequency $\left(\mathrm{F}_{0}\right)$ peak on the tonic syllable is low, and the $\mathrm{F}_{0}$ on the post tonic syllable is high. In words with the falling tone, the tonic syllable has a high $\mathrm{F}_{0}$ peak, and the post tonic syllable is low. Figures 5 and 6 show the average pitch peak for the tonic and post tonic syllable of the long rising and the long falling tones, respectively, in the speech of informant \#1. 


\section{Figure 5}

Informant \#1: CVCV-LR



Figure 6

Informant \#1: CVCV-LF

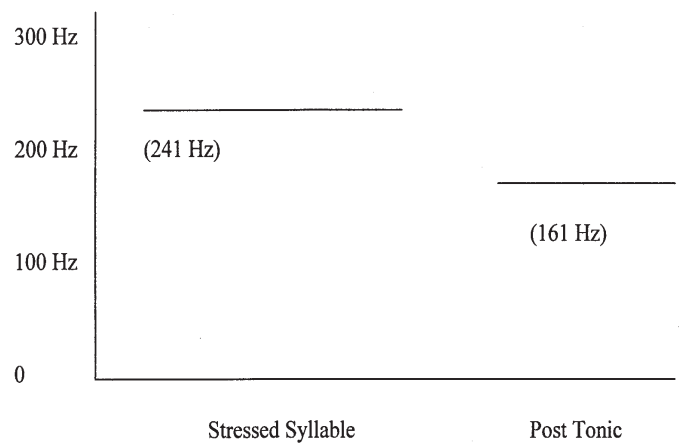

Figures 7 and 8 are actual example of the $\mathrm{F}_{0}$ on contrasting forms in the speech of informant \#1. These pitch contours are taken directly from Praat. The pitch contours of the two words were cut from the sentence context and pasted next to each other to illustrate the contrast. In figure 7, for example, the first part of the graph depicts both syllables of the word muari, which has a falling tone. The second part of the graph depicts both syllables of the word meəra, which has a rising tone. In figure 8 the same is true for driawi and driwi. 
Figure 7: muəri(LF) / meəra(LR)

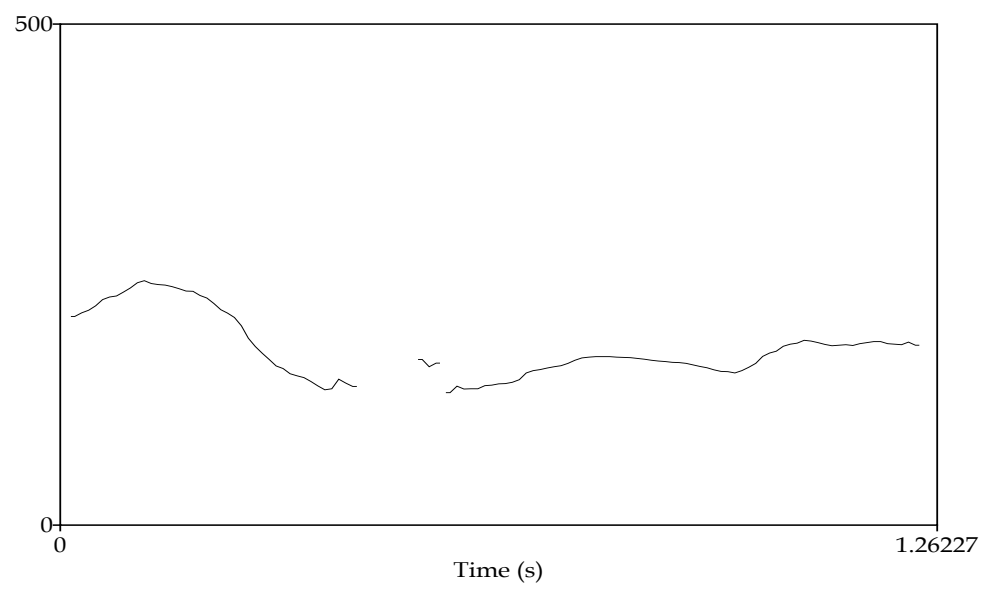

$\begin{array}{lllllll}\mathrm{m} \text { แə } & \mathrm{r} & \mathrm{i} & \mathrm{m} & \varepsilon & \mathrm{r} & \mathrm{a}\end{array}$

Figure 8: driəwi(LF) / driwi(LR)

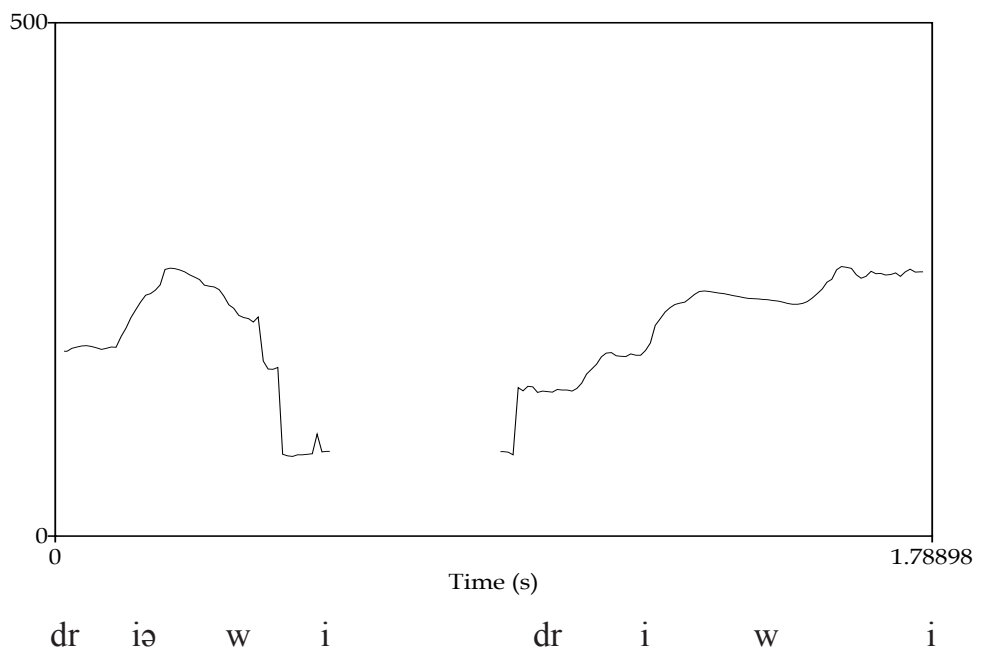

The older generation also has distinctive oppositions on long final syllables. These tonemic oppositions are realized as an early pitch peak for the long falling, and as a late pitch peak for the long rising. The same $\mathrm{F}_{0}$ contour that covers two syllable in the long non-final position is compressed into one syllable in long final position, making the pitch contour on the stressed syllable distinctive. There is no significant absolute height difference between the two tones, as has been claimed for the standard language. Figures 9 and 10 are idealized contours which show the average place- 
ment of the $\mathrm{F}_{0}$ peak for the long falling and the long rising tones, respectively, in the speech of informant \#1.

Figure 9

Informant \#1: CVC-LF

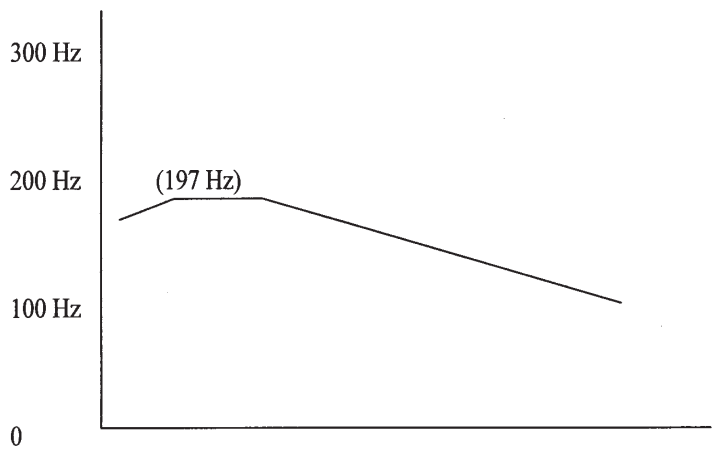

Figure 10

Informant \#1: CVC-LR

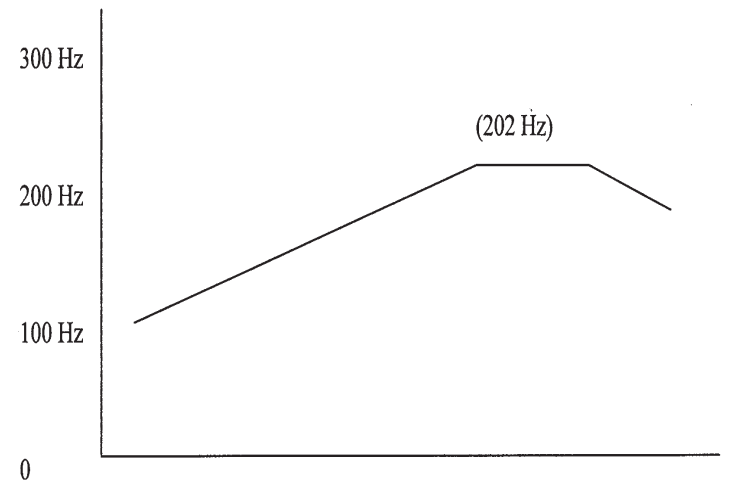

Figures 11 and 12 are actual examples of contrasting tone contours for long final syllables in the speech of informant \#1. These were also taken from Praat and pasted together to show the contrast. 
Figure 11: nuəč(LF) / huč(LR)

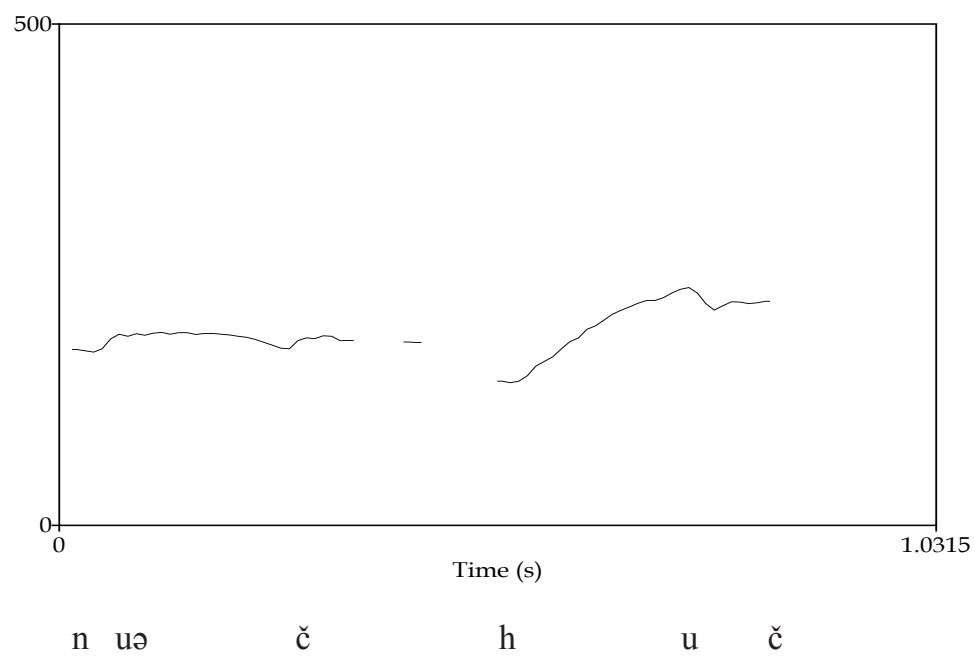

Figure 12: $\operatorname{peət}(\mathrm{LF}) / \operatorname{peət}(\mathrm{LR})$

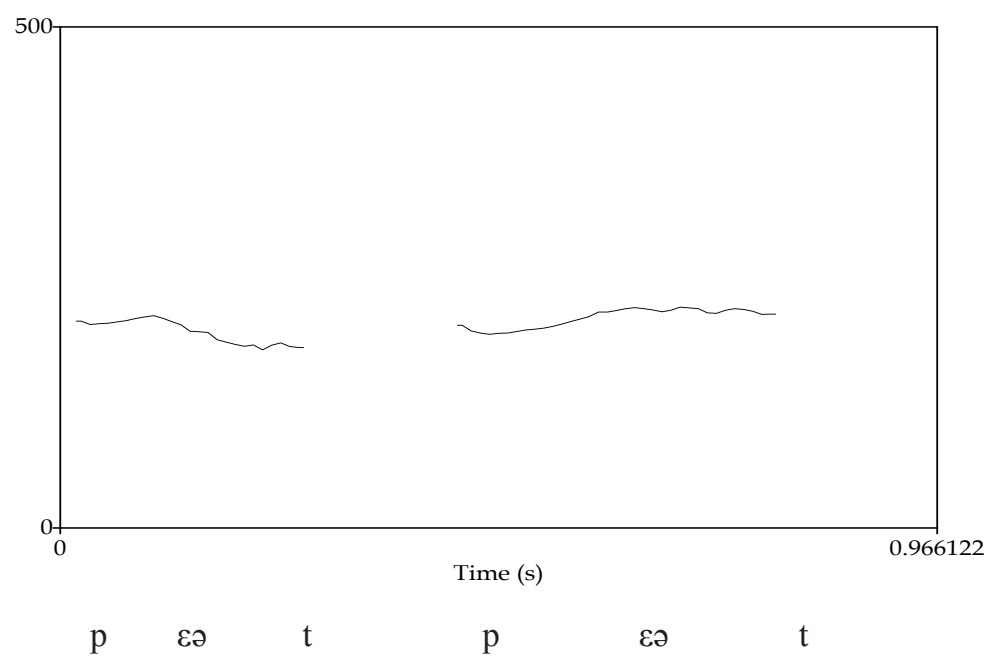

Finally, the older generation has no tonemic oppositions on short syllables. The short syllable under stress is not marked by any contrast of tone. Figure 13 illustrates the average $\mathrm{F}_{0}$ height and typical contour on a short stressed syllable in the speech of informant \#1. Figure 14 is an illustration of two actual forms analyzed in Praat. Both of these forms should be short rising according to Isačenko's description of 1939; they are both falling here. 
Figure 13

Informant \#1: Short

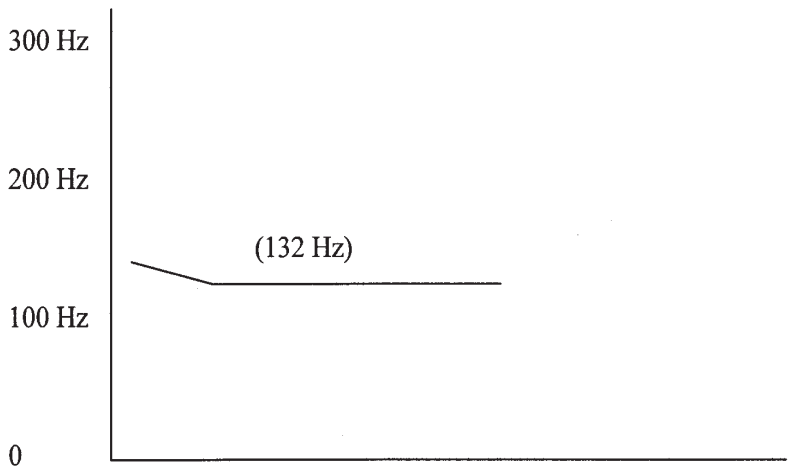

Figure 14: səx / xəd

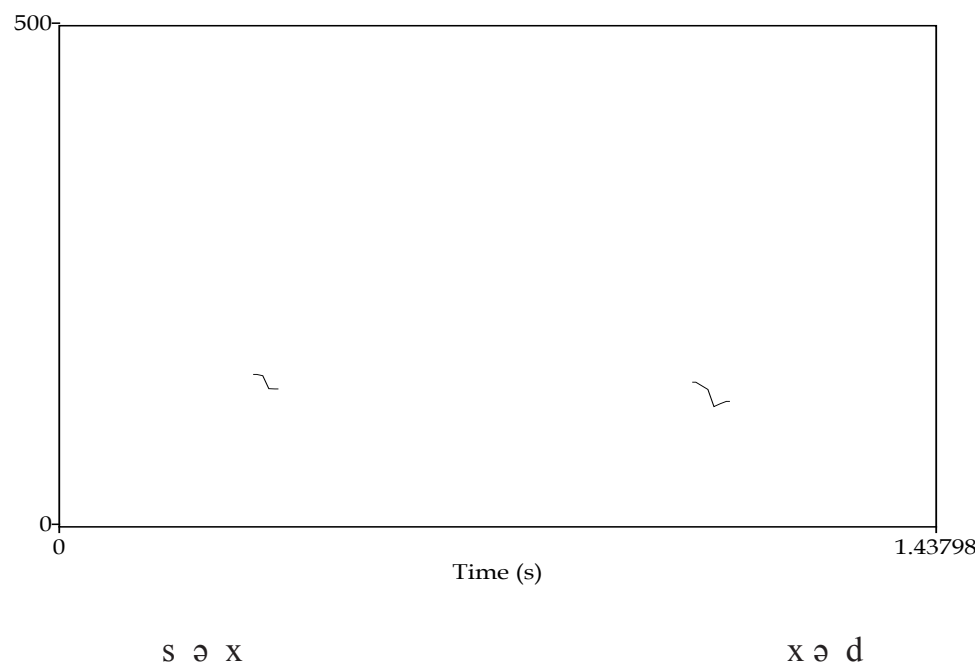

We have thus far used forms from the speech of informant \#1 to illustrate tonemic oppositions for the older generation. This is possible because the tonemic contrasts are uniform for all three representatives of this group. Figures 15, 16, 17 and 18 below are additional examples of tonemic contrasts in the speech of the other informants of the older generation. 
Figure 15: CVCV \#2 hrušqa(LF) / duša(LR)

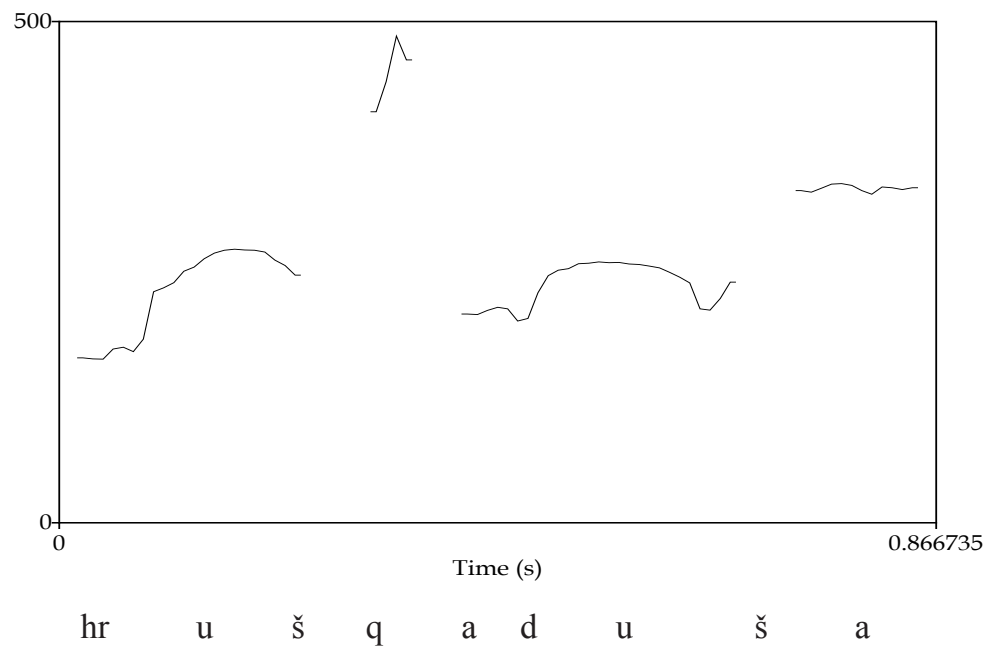

Figure 16: CVC \#2 peət(LR) / peət(LF)

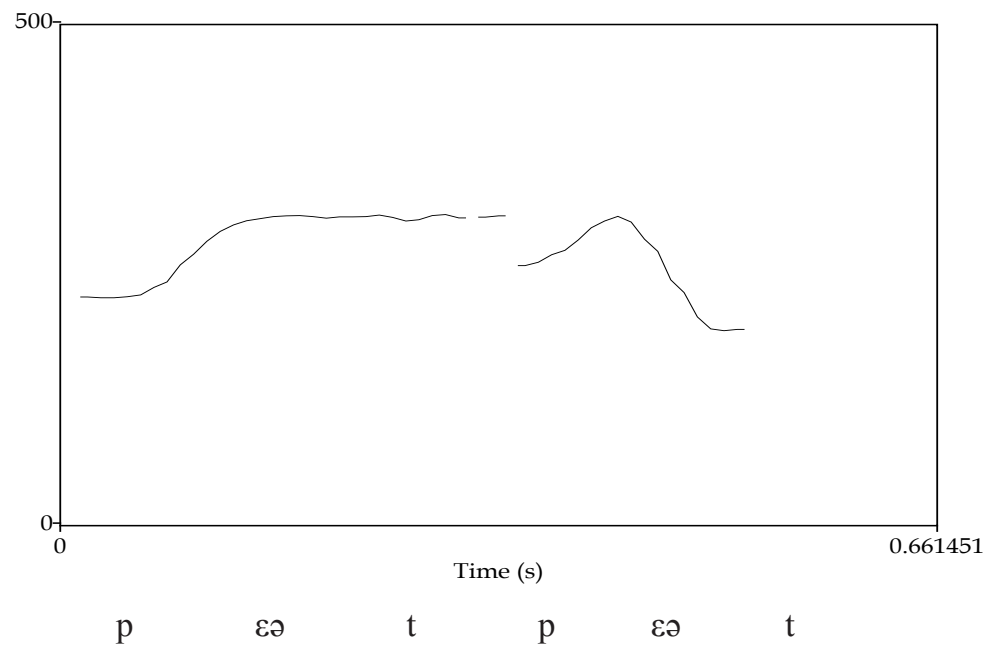

For the older generation of Sele the linguistic situation, at least as far as tonemic oppositions go, seems to be much as was described by Neweklowsky for the rest of Rož in 1973. The only significant difference is that he found no tonal contrasts on long final syllables. These oppositions do occur in the speech of the older generation in Sele, which is not the case in Neweklowsky's data. Like these date, however, there are no tonemic oppositions on short syllables. On long syllables the tone is realized 
Figure 17: CVCV \#3 driwi(LR) / driəwi(LF)

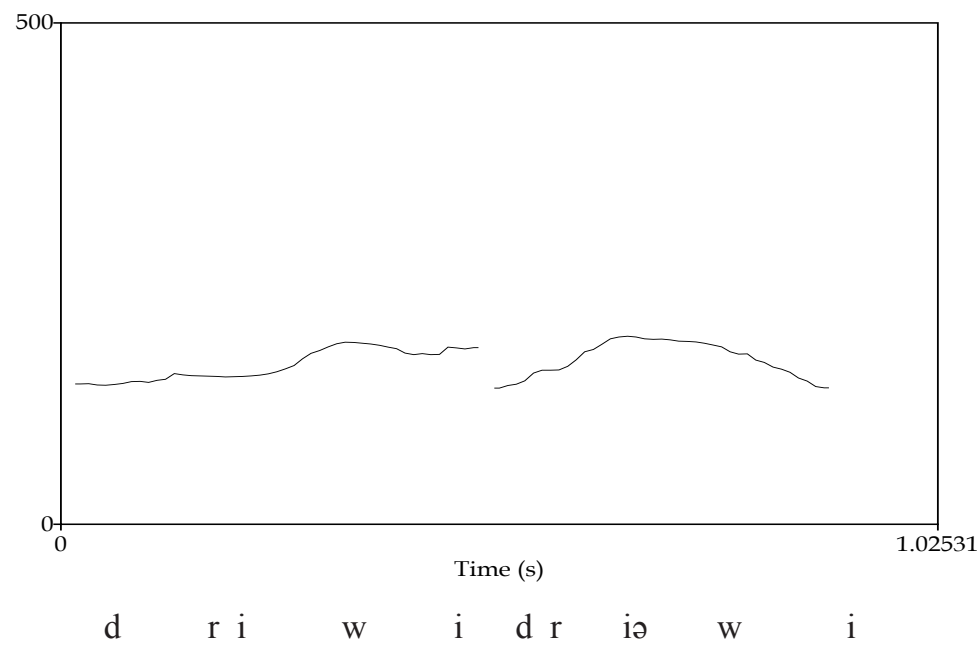

Figure 18: CVC(short) \#3 jəd(F?) / xəd(R?)

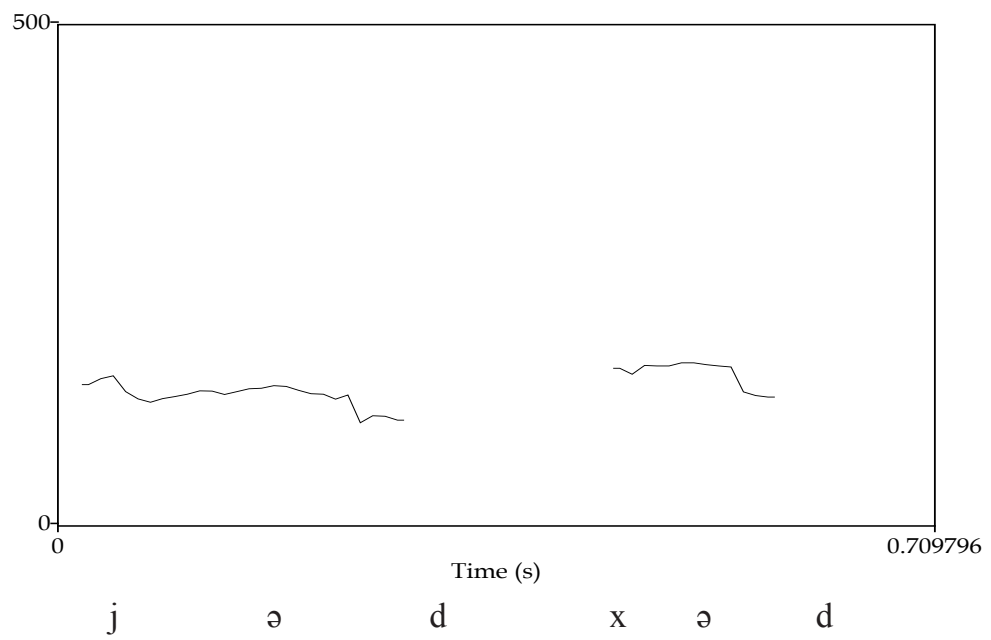

across the entire word. For Sele this means that the contour of final long syllables is distinctive and that in non-final syllables the relative height of the tonic and post tonic syllables is distinctive. Figure 19 is a summary of the data from the older generation. It gives the average pitch peak for each syllable; the percentages in parentheses give the relative height of the tonic to the post tonic syllable. 
Figure 19

Older Generation

$\begin{array}{lll} & \text { CVCV-LR } & \text { CVCV-LF } \\ \# 1 & 186 / 223(83 \%) & 241 / 161(67 \%) \\ \# 2 & 228 / 286(80 \%) & 300 / 236(79 \%) \\ \# 3 & 134 / 163(82 \%) & 171 / 126(74 \%) \\ & \text { CVC-LR } & \text { CVC-LF } \\ \# 1 & 202 & 197 \text { (contour) } \\ \# 2 & 293 & 269 \text { (contour) } \\ \# 3 & 151 & 149 \text { (contour) }\end{array}$

Short Syllables: No Tonemic Oppositions

\subsection{Representatives of the younger generation}

The analysis of the tonemic oppositions in the speech of the younger generation shows what appear to be interesting differences. The most striking difference is that the forms are not as uniform as they are in the speech of the older generation. The oldest member of the younger generation (\#4, born in 1976) has the same tonemic oppositions as the older generation on long non-final syllables: the tonemic contrast between long falling and long rising covers both the tonic and post tonic syllables; in words with long falling tone the tonic syllable is high and the post tonic is low; and in words with long rising tone the opposite is true. Figures 20 and 21 are examples of long non-final contrastive tones in the speech of informant \#4. These forms are also pasted together to show the contrast.

Figure 20: dedi(LF) / hoəba(LR)




Figure 21: driowi(LF) / driwi(LR)

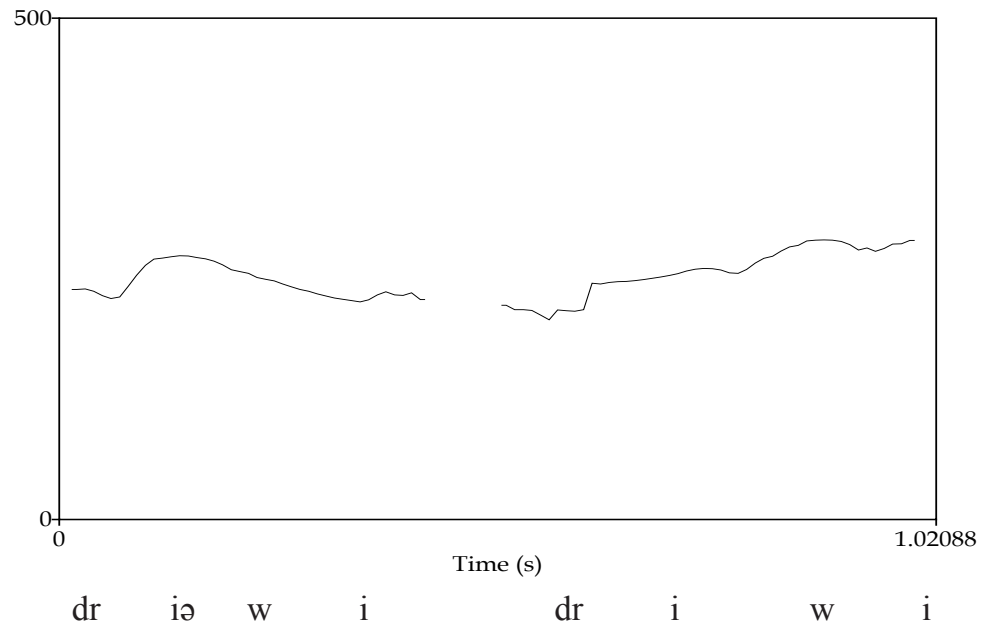

When we turn to informant \#4's final syllables, however, we find a difference as compared to the older generation. She has no tonemic oppositions in final syllables, neither in long or in short, and the contour of these final stressed syllables is not distinctive. Tones in the speech of informant \#4 are just as those in the system described by Neweklowsky for the rest of Rož. Figures 22 and 23 are examples of long and short final syllables, respectively, in the speech of informant $\# 4$.

Figure 22: mej(LF?) / prej(LR?)

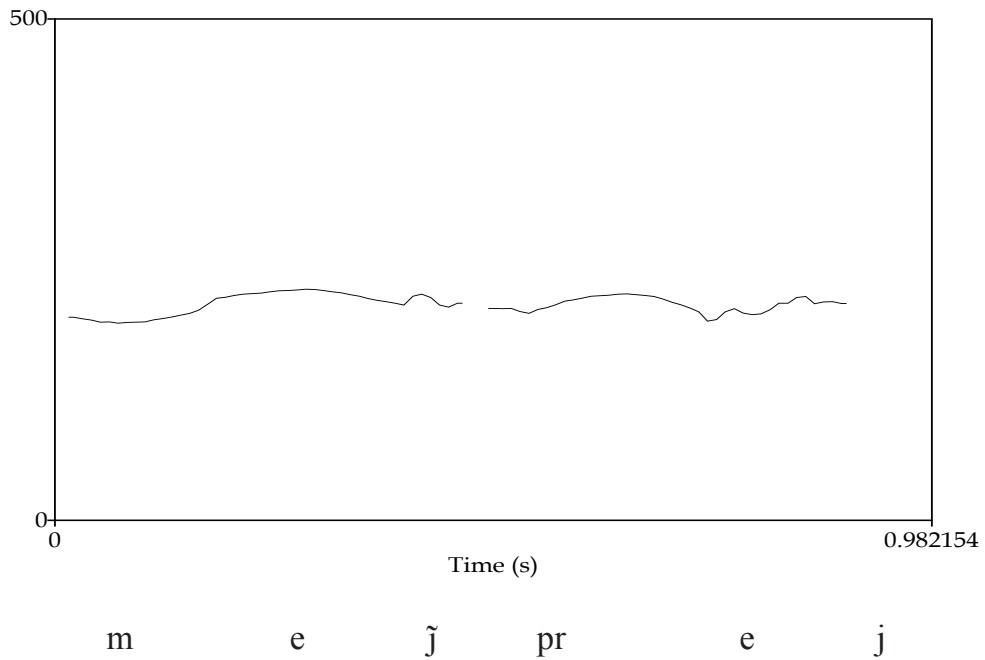


Figure 23: $\operatorname{cox}(F$ ?) / səx(R?)

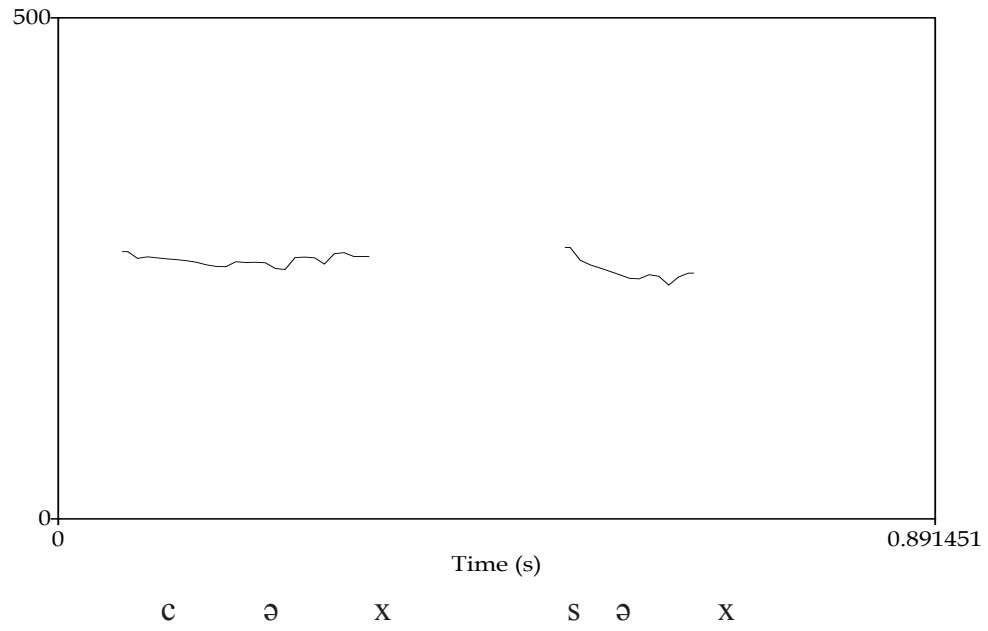

As will now be shown, the tonemic situation for the informants from the younger generation is not as uniform as the one for the representatives of the older generation, and this lack of uniformity is probably an indication that the system is changing. Tones in the speech of informants \#5 and \#7 are again different from those described for informant \#4. These two informants do have tonemic oppositions that are realized across the entire word in long non-final stressed syllables, but the oppositions are not the same as for the older generation. For them, the original long rising has the $\mathrm{F}_{0}$ peak on the tonic and the post tonic syllables at about the same height; in other words, the stressed syllable is low and the post tonic syllable is also low. The long falling tone, on the other hand, is just like that of the older generation and of informant \#4. The tonic syllable is high and the post tonic syllable is relatively low. Figures 24 and 25

\section{Figure 24}

Informant \#5: CVCV-LF

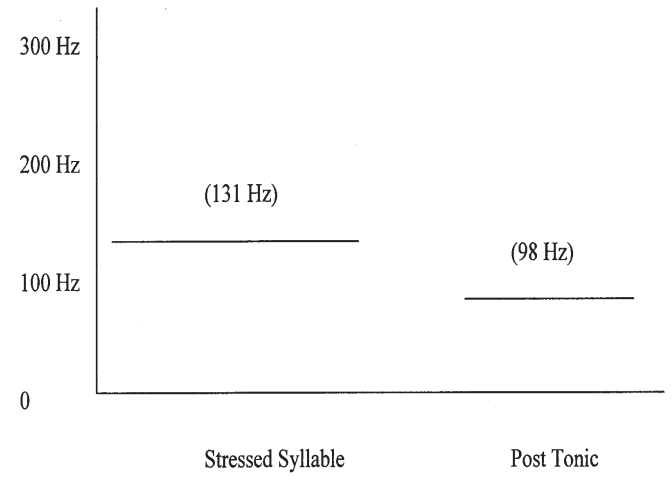




\section{Figure 25}

Informant \#5: CVCV-LR

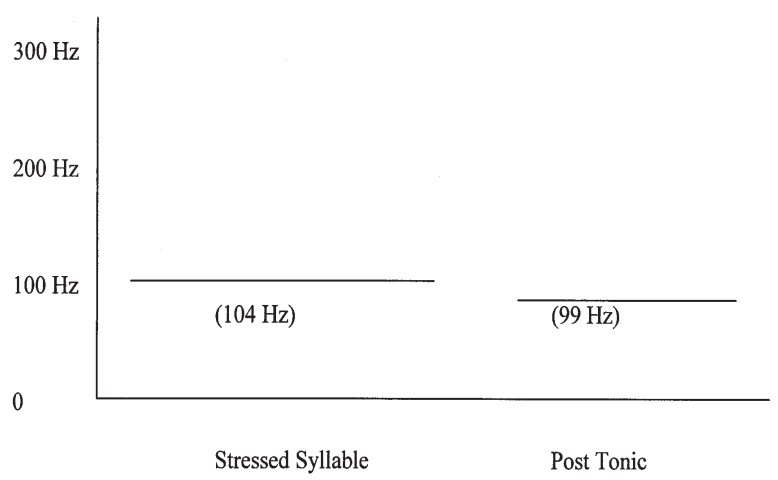

depict the average height of the tonic and post tonic syllables in the speech of informant $\# 5$. These patterns are consistent throughout the speech of informants \#5 and \#7.

Figure 26 is an example of the contrast discussed above. The first form, pori, is long falling and, therefore, has a high $\mathrm{F}_{0}$ on the tonic syllable and a low $\mathrm{F}_{0}$ peak on the post tonic syllable. The second form, hori, is long rising. Both syllables have about the same $\mathrm{F}_{0}$ height. These words are from the speech of informant \#5.

Figure 26: pori(LF) / hori(LR)




Figure 27 also depicts forms from the speech of informant \#5. These are examples of the lack of tonemic contrast in words with original long falling and long rising tones in final position. Both of these words have a slight rise through the vowel and the approximate.

Figure 27: $\operatorname{dow} x(L F ?) / \operatorname{dow} x(L R ?)$

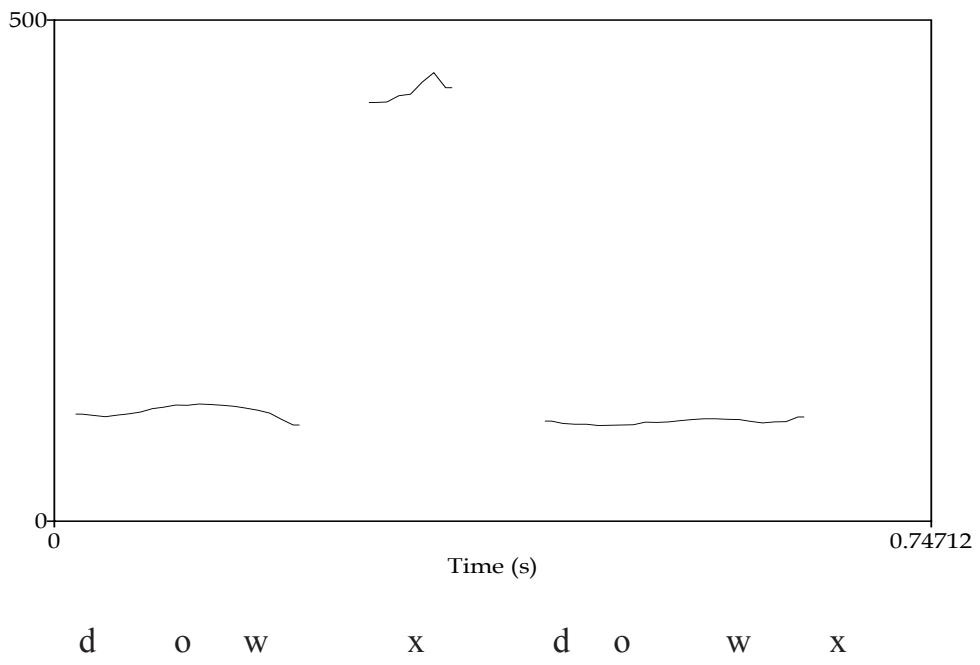

Figure 28

Informant \#6: CVCV-LF/LR

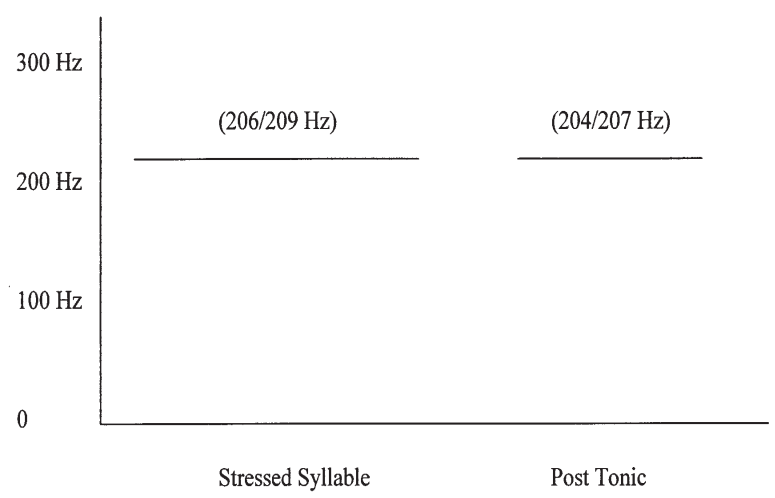


Figure 29: Informant \#6, muəri(LF?) / juni(LR?)



Finally, informant \#6 has no tonemic oppositions at all, neither in long versus short syllables, or in final versus in non-final position. In long non-final syllables both the tonic and post tonic syllables are approximately the same height. Figure 28 illustrates the average $\mathrm{F}_{0}$ peak of the tonic and post tonic syllable in the speech of informant \#6. The first number in parentheses is the original long falling, and the second number is for the long rising tone. Figure 29 illustrates the $\mathrm{F}_{0}$ contour on the forms muəri, and juni, which are expected to be, respectively, long falling and long rising. These forms show no tonemic contrast.

Figure 30: $\operatorname{dr} \boldsymbol{x}(\mathrm{R} ?) / \operatorname{cox}(\mathrm{F} ?)$

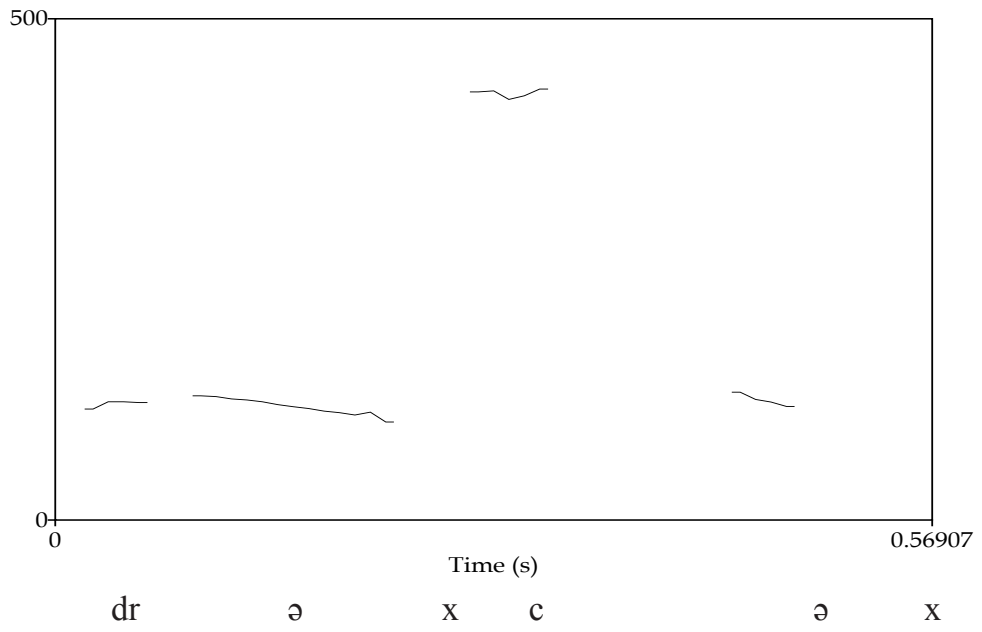


Figure 31: səx(R?) / jəx(F?)



None of the representatives of the younger generation (\#\#4, 5, 6, 7) has tonemic oppositions on short syllables. Figures 30 and 31 are examples of short syllables from the speech of informant \#7. Both of these should show contrasts according to Isačenko, but here there is none.

Figure 32 is a summary of the different types of tonemic contrasts that we find in the speech of the representatives of the younger generation. The percentages show the relative difference between the $\mathrm{F}_{0}$ of the tonic and post tonic syllable.

\section{Figure 32}

\section{Younger Generation}

$\begin{array}{lll}\text { \#4 ('76) } & \text { CVCV-LR } & \text { CVCV-LF } \\ \text { \#5 ('85) } & 1041 / 245(86 \%) & 251 / 203(81 \%) \\ \# 7(' 82)-p & 113 / 114(99 \%) & 131 / 98(75 \%) \\ \# 6(' 86)-p & 206 / 204(99 \%) & 128 / 103(80 \%) \\ & & 209 / 207(99 \%) \\ \# 4 & \underline{\text { CVC-LR }} & \text { CVC-LF } \\ \# 5 & 235 & 245(\text { no opp) } \\ \# 6 & 106 & 105(\text { no opp) } \\ \# 7 & 210 & 215(\text { no opp) } \\ & 113 & 118(\text { no opp) }\end{array}$

Short: No Tonemic Oppositions 


\section{Conclusion}

When we combine the older and the younger generations for the sake of comparison, we find several groupings among the informants, groupings which, we suggest, are significant.

\section{Figure 33}

$\begin{array}{ll}\underline{\text { Informants }} & \text { Stages of Change } \\ 1,2,3 & \text { CVCV: Relative Height of Tonic \& Post Tonic } \\ & \text { CVC: Distinctive Contour } \\ & \text { Short: No Tonemic Oppositions } \\ 4 & \text { CVCV: Same as 1,2,3 } \\ & \text { CVC: No Tonemic Oppositions } \\ & \text { Short: No Tonemic Oppositions } \\ 5,7 & \text { CVCV: LR - Both High, LF - Same as 1,2,3,4 } \\ & \text { CVC: No Tonemic Oppositions } \\ & \text { Short: No Tonemic Oppositions } \\ 6 & \text { No Tonemic Oppositions }\end{array}$

Figure 33 depicts what may well be four stages of change in the system of tonemic oppositions in Sele. Indeed, it may be that the stage that predates the first stage here is the one described by Isačenko in 1939: for in his description Sele has tonemic oppositions on both short and long syllables and in final and non-final position, i.e., what may be considered a maximal system; the first stage from the analysis of contemporary Sele speech shows one neutralization in Isačenko's system (which, we emphasize, was not independently confirmed).

1) The first stage here, the speech of the three oldest informants, has lost oppositions on short syllables. Their speech is characterized by tonemic oppositions on long syllables, both non-final and final. For both of these contexts the tonemic contrasts seem to be spread out across the entire word. If the accent is on a non-final syllable, the tone is realized in the relative height difference between the tonic and the post tonic syllable: the falling tone has a high tonic and low post tonic syllable, whereas the rising tone has a low tonic and high post tonic syllable. If the accent is on the final syllable, this same contrast is compressed into this single syllable, giving it a contrastive contour. There are no tonemic oppositions on short syllables in the speech of the older generation.

2) The second stage is represented by informant \#4, who (born in 1976) is the oldest member of the younger generation. This informant's age places her in between the two groups, and her speech represents an in- 
termediate pattern. On long non-final syllables the tonemic oppositions between rising and falling tones are the same in her speech as they are in the speech of the older generation. Her speech departs from that of the older generation in that she does not have contrastive tones on long final syllables. She also does not have tonemic oppositions on short syllables. It is also interesting, especially if we consider her speech to be a stage in between the older and younger generations, that her tonemic contrasts are the same as those described for the rest of the Rož dialect outside of Sele.

3) The third stage is represented by the speech of informants \#5 and \#7. These speakers also have no tonemic oppositions on short syllables and no contrastive tones on long final syllables. On long non-final syllables the speech of these informants is characterized by a tonemic opposition, but it is different from the opposition we have seen in informants $1,2,3$ and 4. In their speech the falling tone looks the same as it does in the older generation and in the speech of informant \#4. The tonic syllable is high and the post tonic syllable is low. In words with the original rising tone both the tonic and the post tonic syllable have a $\mathrm{F}_{0}$ of the same height. It may be that the tonemic oppositions are being lost as one of the contrasting tones is neutralized.

4) The final stage is represented by informant \#6. This speaker has no tonemic oppositions.

As noted, the speech of the three older informants is tonemically uniform, while the speech of the younger ones is not. On the one hand, the older-generation uniformity makes us confident that our conclusions for them are correct; the youngergeneration lack of uniformity, on the other, calls out for many more data. We have mentioned two factors which may explain some or all of this non-uniformity: (1) the age differences, especially the difference between informants \#4 and the other three which seems to mirror the overall diachronic diminution of tonemic oppositions; and (2) the fact that \#4 studied Slovene at the university level. More important, perhaps, is another very plausible factor, namely (3) the result of influence from other dialects. ${ }^{8}$ We should keep in mind that informant \#6, who has no tonemic contrasts, and informant \#7, who has limited but different tonemic contrasts, both have one parent from Podjuna. As mentioned in section 3 above the tonemic oppositions of the Podjuna dialects are different from those in Rož. Specifically, long non-final tones are distinguished not by the relative height of the tonic as opposed to the post tonic, but by the height of the pitch peak of the stressed syllable of the falling as opposed to the rising. The original falling is a high tone and the rising is a low tone (Neweklowsky 231, Logar 227). The influence of a mother migrating from a different dialect area

${ }^{8}$ Two decades ago the second author noted several apparent changes (in morphology and syntax) in the speech of the younger generations which were best described as being due to the influence of other Carinthian Slovene dialects (Priestly 1988). If this factor was indeed influential in the 1980 s, it is very likely that it is currently no less, and maybe even more, influential now. 
may well explain developments in the speech of informants \#6 and \#7, but it does not explain why informant $\# 5$, who does not have either parent from Podjuna, has the same tone contrasts as informant \#7. Although none of the factors mentioned here can be dismissed, we suggest that it is more likely that the lack of uniformity in the tonemic patterns of the younger generation is an indication of the degradation of the original prosodic system.

Finally, the uniformity of the tonemic oppositions in the speech of the older generation, the apparent middle stage observed in the speech of informant \#4, which conforms to the situation in the rest of the Rož dialect, and the lack of uniformity in the tonemic patters of the other members of the younger generation, as well as the complete lack of tonemic oppositions in the speech of one member of the younger generation, all point to the gradual loss of tonemic oppositions in Sele.

\section{References}

Boersma, Paul and David Weenink. 2007. Praat 4.6.13. www.praat.org.

Greenberg, Marc L. 2000. A Historical Phonology of the Slovene Language (= Historical Phonology of the Slavic Languages, vol. 13). Heidelberg: Universitätsverlag C. Winter.

Hombert, Jean-Marie. 1978. "Consonant Types, Vowel Quality, and Tone." in Tone (ed. Victoria A. Fromkin): 77-112. New York: Academic Press.

Isačenko, A. V. 1939. Narečje vasi Sele na Rožu. Ljubljana: Znanstveno društvo.

Jurgec, Peter. 2007. "Acoustic Analysis of Tones in Contemporary Standard Slovene: Preliminary Findings.” Slovenski jezik/Slovene Linguistic Studies 6: 195-207.

Logar, Tine. 1996. Dialektološke in jezikovnozgodovinske razprave. Ljubljana: Znanstvenoraziskovalni center SAZU, Inštitut za slovenski jezik Frana Ramovša.

Neweklowsky, Gerhard. 1973. Slowenische Akzentstudien: Akustische und linguistische Untersuchungen am Material slowenischer Mundarten aus Kärnten. Wien: Verlag der Österreichischen Akademie der Wissenschaften.

Priestly, Tom. 1988. "Accelerated grammatical changes in Carinthian Slovene: Dialect mixture, or 'linguistic decay'?" Canadian Slavonic Papers 30 (= Canadian Contributions to the X International Congress of Slavists, Sofia 1988): 62-80.

- - 1994. "Isačenko's Narečje vasi Sele na Rožu: An Assessment after Half a Century." Slavistična revija 42: 215-28.

Ramovš, Fran. 1935. Historična gramatika slovenskega jezika VII: Dialekti. Ljubljana: Znanstveno društvo.

Reindl, Don. 2005. The Effects of Historical German-Slovene Language Contact on the Slovene Language. Ph.D. dissertation, Indiana University.

Srebot-Rejec, Tatjana. 1988. Word Accent and Vowel Duration in Standard Slovene: An Acoustic and Linguistic Investigation (= Slavistische Beiträge, vol. 226). Munich: Verlag Otto Sagner.

- - 1999. "Iz zgodovine klasifikacije slovenskih narečij na Koroškem in nove naloge slovenske dialektologije." in Logarjev zbornik (ed. Zinka Zorko and Mihaela Koletnik): 16-26. Maribor: Zora. 
Toporišič, Jože. 1967. "Pojmovanje tonemičnosti slovenskega jezika." Slavistična revija 15/1-2: 64-108.

- - 1968. "Liki slovenskih tonemov." Slavistična revija 16: 315-94.

Prispelo avgusta 2008, sprejeto januarja 2009

Received August 2008, accepted January 2009

\section{Tonemska nasprotja v slovenskem govoru vasi Sele: izguba tonemskosti na avstrijskem Koroškem}

Prispevek opisuje strojno razčlembo sodobnega stanja tonemskih nasprotij $\mathrm{v}$ slovenskem govoru vasi Sele na avstrijskem Koroškem. Študija, ki je bila izvedena poleti in jeseni 2007 , kaže, da so tonemska nasprotja dosledno ohranjena pri starejši generaciji, medtem ko se pri mlajši generaciji izgubljajo, čeprav ne dosledno.

V študiji je obravnavan govor sedmih informatorjev, treh starejših in štirih mlajših. Na osnovi Priestlyjevega korpusa selških narečnih oblik sta avtorja digitalno posnela vseh sedem informatorjev in pridobljeno gradivo razčlenila s programom Praat 4.6.13. Obravnava kaže, da je pri starejši generaciji tonemsko nasprotje v dolgih nezadnjih zlogih dobro ohranjeno. Pogosto se naglašeni zlogi razlikujejo v poteku tona: prvotni akut ima rastoč potek, medtem ko ima cirkumfleks zgodnji vrhunec in padajoč potek v ostalem delu zloga. Ta razlika ni vedno prisotna $\mathrm{v}$ nezadnjih zlogih, čeprav je tonemskost dosledno realizirana $\mathrm{v}$ okviru celotne besede.

Razčlemba tonemskih nasprotij v govoru mlajše generacije kaže, da so nasprotja manj dosledna kot $v$ govoru starejše generacije. Najstarejša informatorka mlajše generacije, rojena 1. 1976, ima v dolgih nezadnjih zlogih enaka nasprotja, kot jih ima starejša generacija, vendar ne več v zadnjih zlogih. Tudi druga dva informatorja mlajše generacije imata tonemska nasprotja, realizirana $v$ okviru celotne besede, ko gre za dolge nezadnje naglašene zloge, vendar pa nasprotja pri njiju niso enaka kot $\mathrm{v}$ govoru starejše generacije. Eden od mlajših informatorjev nima tonemskih nasprotij. Razlike $\mathrm{v}$ tonemskih nasprotjih $\mathrm{v}$ govoru mlajše generacije kaže, da se v govoru vasi Sele tonemskost postopoma izgublja.

\section{Pitch Oppositions in Sele: Slovene Tone Loss in Austrian Carinthia}

This paper is a description of an instrumental analysis of the contemporary state of tonemic oppositions in the Slovene micro-dialect of Sele in Austrian Carinthia. The study, conducted during the summer and fall of 2007, indicates that tonemic oppositions are uniformly preserved among the older generation and being lost, although not uniformly, among the younger generation.

The study is based on the speech of seven informants, three from the older generation and four from the younger generation. Using forms from Tom Priestly's corpus of Sele dialect materials the authors digitally recorded all seven informants and 
analyzed target forms using Praat 4.6.13. The analysis shows that the older generation clearly has tonemic oppositions on long non-final syllables. Often the accented syllables have contour distinctions: the original acute has a rising contour, while the original circumflex has an early peak and a falling contour through the remainder of the accented syllable. This contour is not always present on non-final syllables, but the tone is consistently realized over the entire word.

The analysis of tonemic oppositions in the speech of the younger generation indicates that the oppositions are not as uniform as they are in the speech of the older generation. The oldest member of the younger generation, born in 1976, has the same tonemic oppositions as the older generation on long non-final syllables, but she has no tonemic oppositions on final syllables. The next two informants from the younger generation also have tonemic oppositions that are realized across the entire word on long non-final stressed syllables, but the oppositions are not the same as for the older generation. Finally, the last informant from the younger generation has no tonemic oppositions at all. This lack of uniformity of the tonemic oppositions in the speech of the younger generation points to the gradual loss of these oppositions in Sele. 